\title{
Barriers and Facilitators of Collaborative Management in Technological Innovation Projects
}

\author{
Sonia Regina Hierro Parolin', Eduardo Vasconcellos², Maricilia Volpato ${ }^{3}$,Alisson Marcelo Laurindo ${ }^{4}$
}

\begin{abstract}
Discussions about innovation tend to a more systemic and cooperative approach in which those networks focused on scientific and technological development are considered. This article aims to identify the barriers and facilitators in the collaborative management process of technological innovation projects and a study has been carried out by the cooperation action for innovation with 17 industries in Brazil. The primary evidence refers to the crucial role of project managers when leading the structural demands, and clarity on the relevance of the communication of strategic guidelines among the organizations involved for the achievement of the results in the industries.
\end{abstract}

Keywords: collaborative management; innovation management; innovation projects.

'UFRGS. Professor of Creativity and Innovation in Graduate Programs and Manager of Technological Services and Innovation at SENAI Paraná, Brazil.Address: 744 Dr. Correa Coelho street, apt. 602. Curitiba - Paraná - Brazil. ZIP 802 I0-350 Phone: +55 4I.3262.1265

E-mail: srhparolin@gmail.com

${ }^{2}$ Holder FEA / USP, Administrator. I08 Dardanelles Street apt. I6IB São Paulo - São Paulo - Brasil. ZIP: 05468-0 I 0 Phone: +55 II .309I.5837 E-mail: epgdvasc@usp.br

${ }^{3}$ Senior Analyst in Innovation at SENAI Paraná, Brazil.Address: 360 Jose Nicco street, home 49 - Curitiba - Paraná - Brazil. ZIP: 8I200-300. Phone: +55 41.327I.9354. E-mail: maricilia.volpato@pr.senai.br

${ }^{4}$ Analyst in Technology and Innovation at SENAI Paraná, Brazil.Address: I 96 Wanda Rocha de Souza street. Curitiba - Paraná - Brazil. ZIP 821 10-440. Phone: +55 41.3271.9868. E-mail: alisson.laurindo@pr.senai.br 


\section{Foreword}

The development of discussions on the competitiveness of Brazilian industry, relevant to the global scenario, points to competitive innovation strategies that have been structured by a network of public and private institutions (SBRAGIA et al, 2006). Therefore, it is possible to note that the innovation process tends towards a systemic approach, through formation of organization networks focused on executing projects systemically in direct and indirect networks. They include several types of organizations in a joint and chain effort for the generation, development and propagation of technological innovations, in a number of ways (MOTA; Lucchesi, 1998). According to Farias et al (2006), in these relationships geared towards cooperation, the institutions operate from technology parks, according to agreements between companies and other institutions such as research centers, universities, financial institutions and development agencies. Established through strategic positioning for obtaining organizational results using innovation, the networks require qualified people to operate collectively in organizations with different values and cultures.

Development of innovation occurs through management of portfolios comprised of successful and critical events that influence the process and effectiveness of the innovation. Farias et al (2006) present Clark and Wheelwright's (1995) typology about problematic and successful projects, in which they evidence sharing, a systemic approach, team responsibility and the role of leadership, among other characteristics of a successful project. In the international literature, there are some studies which posit people as being the differential for attaining innovation (ALIAGA, 2005; Leede; Looise, 2005; Ekvall, 1996).
Another important observation regarding the tendency towards development of innovation projects in collaborative networks is noted by Enkel et al (2009). The author emphasizes that it is less important for companies to have a central laboratory (close innovation) when external knowledge is available.

Regarding cooperation in innovation projects, the research attempted to identify the barriers and facilitators in the collaborative management process of technological innovation projects, within the following spheres: i) strategy, structure and resources; ii) human resources and behavior; iii) technological innovation management and iv) collaborative management of innovation projects. Therefore, a case study was undertaken together with the cooperation initiative for industrial technological innovation, developed by Serviço Nacional de Aprendizagem Industrial do Paraná (SENAI PR), Brazil (National Agency for Industrial Learning in the State of Paraná - SENAI PR), with 17 industrial companies located in the State of Paraná, Brazil.

It is worth noting that the objective of the paper is to contribute to research into the barriers and facilitators in the development of innovation projects in small and medium sized companies. Sparse literature was found regarding this topic for companies of this size.

\section{Model of barriers and facilitators to innovation - BFI}

The model presented in this section is comprised of the components deemed critical for the technological innovation project management process, developed jointly be-

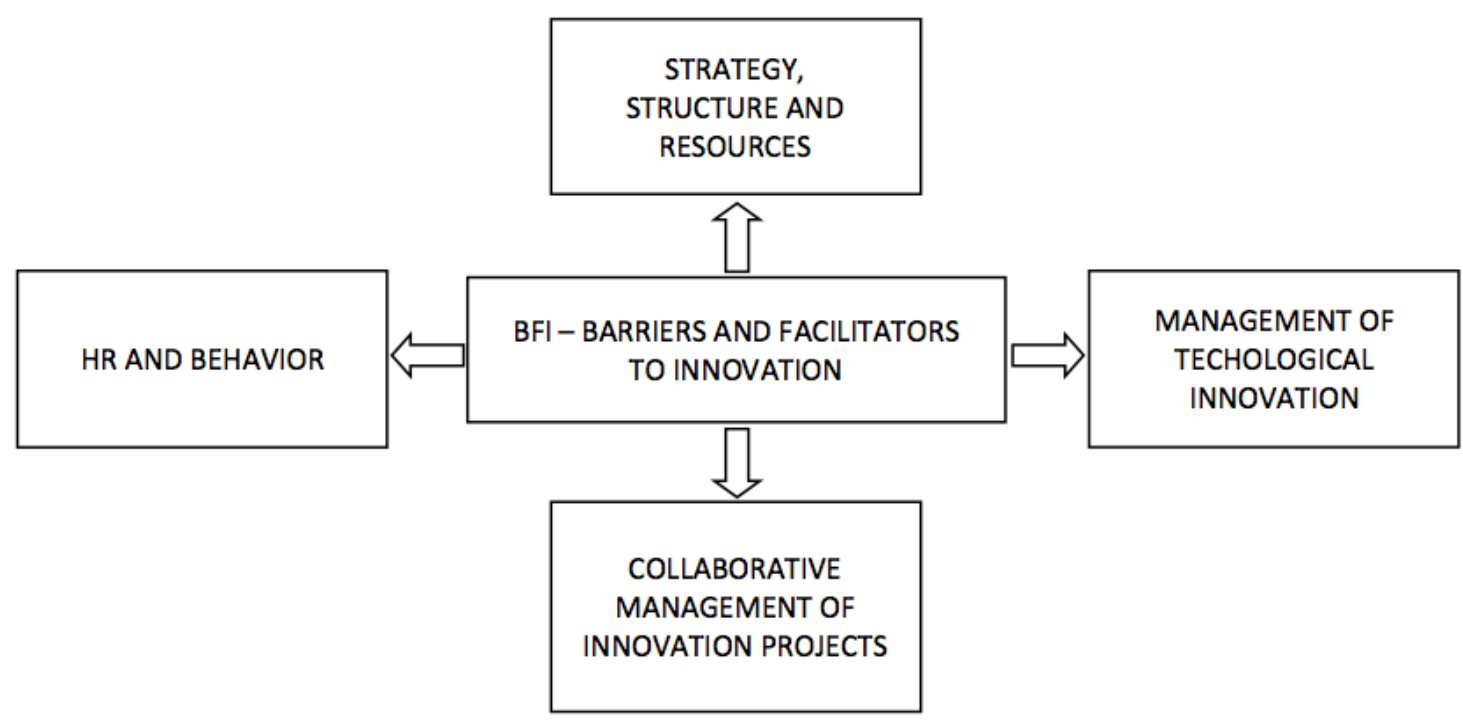

Figure 01: Model of Barriers and Facilitators to Innovation Source: adapted by Vasconcellos et al, 2006.

ISSN: 07 I8-2724. (http://www.jotmi.org)

Journal of Technology Management \& Innovation (c) Universidad Alberto Hurtado, Facultad de Economía y Negocios. 
tween an industrial company and an applied research institution. They both stimulate or hinder innovation, depending on the management strategy selected for all levels. As a result, there are intra-organizational conditions that will determine the level of innovation produced in the company, with greater or lesser intensity (figure $0 \mathrm{l}$ ).

\section{Strategy, structure and resources}

The formulation of a strategy is focused on two components: the dominant, related to turbulence of the market, and the deliberate, developed in stable environments (MINTZBERG, 1998). When dealing with the innovation strategy, certain conditions stand out, such as the investment in technology and internal skills and, especially, the challenge of dispersing innovation throughout the whole organization (JONASH, 200I).

Tidd et al (2008, p. I3I-I48) mention two distinct lines of study regarding technological strategy and innovation: "traditionalist' and 'incremental'. Most authors consider the latter as the most appropriate to deal with the complexity and uncertainty of the innovation process, because it distinctly recognizes that companies must be prepared to adapt their strategy to new information, tendencies and knowledge which they should constantly attempt to obtain. For this reason, the same authors posit, "different types of technological opportunity require different types of strategy and structure" (p. 245), which will reflect on the degree of centralization, delimitation of corporate divisions and interfaces as well as internal and external relations.

Vasconcellos and Hemsley (2003 p. 23-28) conducted studies on innovative structures, their characteristics and how to compare them to traditional frameworks, with emphasis on the structure for projects and issues occurring during the several steps of growth in a given organization. The authors highlight the matrix structure for innovation.

The strategies determine the innovation structures (GALBRAITH; Lawler lii, 1995, P. 04) and require a management profiles different to those present in functional and bureaucratic structures. When creating innovation strategies it is important to consider the cooperative project structures between companies and research institutes as a feasible and faster way to find innovative solutions for companies (SBRAGIA et al, 2006).

\section{Human Resources and behavior}

Executing the strategy aligned to organizational innovation pervades the intra-organizational conditions relevant to culture, organizational climate and management (SLUIS, 2004), through the initiatives of personnel introducing new processes, products, markets or the combination of them within the company. Therefore, the first activity undertaken by innovative companies is executed by their human resources, which must interact and act coherently (ALIAGA, 2005; Leede; Looise, 2005).

Studies about people as differentials for achieving innovation consider integration based on Strategic Human Resource Management (SHRM). It proposes integration between policies and people management practices, considering multidimensional models that evidence certain organizational characteristics inherent to the context and which contribute to results in innovation, including creativity as the input and output of the process (FERRIS et al, 1999;Albuquerque, 2002; Dutra, 2002; Laursen; Foss, 2003; Aliaga, 2005; Leede; Looise, 2005; Martin-Alcazar Et Al, 2005; Parolin; Albuquerque, 20I0). Regarding the barriers and facilitators to creativity in the organizational environment, there are groups of variables based on several studies, especially those in Amabile's researches (1998), which consider encouraging creativity, the task environment as well as resources and organizational hindrances (PAROLIN;Albuquerque, 2010).

Vasconcellos and Hemsley (2003) emphasize the profile of individuals as a requirement for the matrix structure in the development of innovation projects. They point to ten vital competences, among them, the ability to deal with ambiguity, political skills and the ability to perform multiple roles.

Organizational climate is linked to worker motivations, regarding those aspects related to satisfaction at work and has been observed "as a solution to improve professional performance of both productivity and organizational health and worker satisfaction" (CASADO, in Fleury, 2002, p. 257). The organizational climate also involves the psychological aspect for releasing creativity and generating innovative proposals (ALENCAR, 1997). Negativism, disrespect, prejudice, intolerance and stress are unwelcome characteristics that generate relational conflicts which might paralyze team work and hinder cooperation due to the lack of reciprocal trust (CARDINAL et al, 1998).

It is important to stress that most studies regarding the topic attempt to relate creativity and innovation with the organizational climate which, in turn, reflects elements of the organizational culture (McLEAN, 2005, p. 229). Projects developed in cooperation between the industries and research institutes comprise additional challenges in the behavioral field, as a function of the work of teams comprised of people from different institutions and, thus, from different cultures, philosophies, values, etc., in addition to the empowerment of autonomy for the project teams.

ISSN: 07 I8-2724. (http://www.jotmi.org) 


\section{Management of technological innovation}

For companies, using outdated technology might generate a product with reduced market competitiveness. The challenge is "to find the technologies of the future, ensure that the development strategy complies with those technologies and master them to maintain progress, or search for more ambitious goals" (REIS; CARVALHO, 2002, in Bastos, 2002, p. 53). Similarly, the authors listed emphasize the importance of competitive and technological intelligence for innovation. Obviously, the information technology revolution is responsible for successive advances in the ability to transmit information, offering corporate functionality in all areas of organizations (TIDD et al., 2008). Information Technology (IT) is responsible for the growth a new organizational format, one which is more powerful and flexible and combines network structures with new technologies. According to Nolan and Croson (1996), this combination must be guided by effective and a permanently updated company vision of what the company needs to be and its values, in order to provide context and the outline those frontiers within which the networks might be built and destroyed as needed.

Technological innovation management of jointly-developed projects also involves managing knowledge and expertise, creation, "re-creation" and sharing of specific knowledge requiring constant negotiation, under the protection of secrecy and confidentiality agreements between the parties involved, something which does not occur without conflicts between partners (SWAN et al, 1999).

The IT structure permits technological observation from a number of available access points, such as patent databases, scientific journals and specialized publications, etc. The information sources for technological innovation also increase with the acquisition of machines and equipment, information regarding suppliers, participation at trade fairs, congresses, amongst others (TIGRE, 2006, p. II4-II5). According to Sbragia et al (2006, p.62), the information sources leading to innovation may also derive from licensing patents and acquiring know-how.

\section{Collaborative management of innovation projects}

An important definition of 'innovation co-operation' is presented by Tether (2002, p.949) and focuses on combined development between partners of R\&D and technological innovation projects:

"Innovation co-operation means active participation in joint R\&D and other technological innovation projects with other organizations. It does not necessarily imply that both partners derive immediate commercial benefits from the ven- ture. Pure contracting out work, where there is no active participation is not regarded as co-operation."

Innovation co-operation involves correct choices made by partners (inter-firms) to develop co-operative projects. Miotti and Sachwald (2003) outline the different motivational factors in these choices - why and with whom - which differ substantially according to the technological density of the sectors. Those decisions, which involve high cost and risk factors for innovation, information about the market and show a higher propensity for R\&D co-operation, occur between high technological density companies active on the frontier of technological knowledge and are designated by the authors as horizontal cooperation (where cooperation between competitors may also occur). In sectors with lower technological density, decisions about cooperation usually occur vertically, even with clients collaborating to resolve problems.

In Brazil, several studies have evidenced that the more networks are consolidated, the better the results regarding innovation (MOTA; Lucchesi, 1998; Sato, 2005;Tigre, 2006) and they might be defined "as a network of public and private institutions that interact to foster the scientific and technological development of a country", which participate in the National Innovation System - (Sistema Nacional de Inovação, SNI) - (SBRAGIA et al, 2006, p. 19).

Tidd et al (2008, p. 3 II) defend that "no form of collaboration is ideal in any general sense" and that the "technological and market characteristics will limit the options, and the culture of the company and the strategic considerations will determine what is possible and what is desirable". The authors present six types of collaboration (outsourcing/ provision relations, licensing, consortiums, strategic alliances, joint ventures and networks) as well as their duration, advantages and disadvantages.

Sbragia et al (2006, p. 99-II2) present several institutional formats for collaboration between companies, universities and research institutes, of which those that are specifically arranged for collaborative technological innovation projects stand out: out-sourced, out-sourced services, cooperative research programs or projects and agreements of association and research consortiums. Investment in cooperative research has grown more than resources allocated individually by companies with their own R\&D. Contractual models preserve intellectual property rights between the parties and, at the same time, promote exchange of research results with effective commercial benefits.

Regarding the intra-organizational aspects of collaborative projects, Zell (200I), believes that the lack of a cooperation network in companies hinders creation of a learning activity

ISSN: 07 I8-2724. (http://www.jotmi.org)

Journal of Technology Management \& Innovation (c) Universidad Alberto Hurtado, Facultad de Economía y Negocios. 
structure in terms of social activity based on communication. For the model to assess the barriers and facilitators to innovation presented here, the practice of joint ventures, coalitions, out-sourcing, etc. by organizations are considered innovative structures in cooperation networks which are aligned to the strategic objective. These practices require clarity in their objectives and adaptation to the strategy, focus on core skills, high levels of cooperation between the departments and organizations, amongst other challenging elements faced by organizations dedicated to a strategy which attempts to break with systems of control in functional structures.

\section{Research methodology}

Based on the proposed goal, the guiding methodology of the research is characterized as non-experimental, descriptiveexploratory using a qualitative approach with cross section through a case study (GIL, 1999; Yin, 200I). According to Roesch (1999, p. 137), descriptive research "does not attempt to explain or show causal relations, as does experimental research (...), it seeks the information required for action or prediction (...), it does not explain the 'why', although it can associate certain results to groups of respondents". Research with cross sections, on the other hand, does not comprise several conditioning variables of the context. The definitions that support qualitative-descriptive studies consider that "the qualitative method differs, firstly, from the quantitative because it does not apply statistical methodology as a basis for analyzing a problem" (RICHARDSON, 1989, p. 38). Such an approach seems apt when the intention is to learn and analyze social phenomena, for it enables identification of the subjective aspects of the social phenomena in the organizational environment.

Therefore, a study was performed together with cooperation initiative for industrial technological innovation through applied research, developed by Serviço Nacional de Aprendizagem Industrial do Paraná (SENAI PR) (National Agency for Industrial Learning in the State of Paraná), Brazil, and Brazilian industries based in the State of Paraná. The data were collected from seventeen technological innovation projects (applied research) jointly developed in the sphere of "Edital SENAI SESI de Inovação" (see table 02). As a result, the objective is to contribute to the discussion about collaborative forms for managing technological innovation and to acquire elements to further develop the innovation culture as a competitive factor for Brazilian industry.

The data collection instrument was developed with thirty eight objective questions and one open question, in addition to the autobiographical and professional data, which was self-applied by the respondents and sent to the representatives of the industrial companies as well as SENAI PR. The objective questions were arranged according to the four analysis variables that integrate the BFI Model for Collaborative Innovation Projects, of which there are: a) 10 questions regarding strategy, structure and resources; b) II questions regarding human resources and behavior; c) 07 questions on management of technological innovation; and d) 10 questions concerning collaborative management of innovation projects. Analysis of the data from the objective questions was executed using the average answers, graded from zero to ten, where 10 is the maximum grade relevant to the respondent's perception. The results are presented by groups of variables, comprising the averages of the company representatives (column $A$ ) and the average of representatives from SENAI PR (column B).

The same question was put to both the companies' project representatives and SENAI PR's respondents: "Which barriers and facilitators could be cited (in your company/institution) regarding management and collaborative development of technological innovation projects with companies?" The answers were compared and analyzed relevant to the organizations' context and specifics and comprised the analysis of results.

Regarding the research sample, the aim was to comprise pairs of representatives from the seventeen projects selected, in which there was one representative from the company (A) and one from SENAI PR (B), for each project. There was a return equivalent to 10 projects, that is, a return rate slightly above $50 \%$.

\section{Introduction and discussion of the results}

\section{Case: SENAI-Industry cooperation for technological innovation}

SENAI (National Agency for Industrial Learning), which is present in every Brazilian state, was created by Decree-law $N^{\circ} 4.048$, from 0I/22/1942 and adjusted by Decree $N^{\circ} 494$ from 01/10/1962 responsible for organizing and managing learning schools for industrial workers and similar activities, and cooperation in the development of technological research to raise the interest of the industry.

SENAI Departamento Nacional (SENAI DN) (National Department) has been acting to further the development of technological innovation since 2004 and its primary activity, until now, has been the "Call to Innovation" which aims to provide resources to SENAI Schools and Technology Centers countrywide to develop collaborative technological innovation projects, through the submission, evaluation and selection of projects submitted by companies from the industrial sector, for a predetermined period. This project concerns the call and selection of technological innovation 


\begin{tabular}{|c|c|c|c|c|c|c|}
\hline $\begin{array}{l}\text { Yearl } \\
\text { Status }\end{array}$ & Project name & $\begin{array}{l}\text { Type of Inno- } \\
\text { vation }\end{array}$ & Industry & Patents Required & Location/ PR & $\begin{array}{l}\text { Industrial } \\
\text { Sector }\end{array}$ \\
\hline \multirow[t]{2}{*}{$\begin{array}{l}2007 \\
\text { Finalized }\end{array}$} & "Ultra frozen cake dough" & $\begin{array}{l}\text { Process and } \\
\text { product }\end{array}$ & El Shadai & $\begin{array}{l}\text { PI 0802968-7 } \\
\text { PI 0802994-6 }\end{array}$ & Chopinzinho & $\begin{array}{l}\text { Food and } \\
\text { Beverages }\end{array}$ \\
\hline & $\begin{array}{l}\text { "EcoChic - fashion and gar- } \\
\text { ments" }\end{array}$ & $\begin{array}{l}\text { Product and } \\
\text { business }\end{array}$ & Abicci & Not applicable. & Curitiba & $\begin{array}{l}\text { Textile and } \\
\text { Garments }\end{array}$ \\
\hline $\begin{array}{l}2008 \\
\text { Finalized }\end{array}$ & "Upholstered Architecture" & Process & Molufan & PI 09|3255-4 & Arapongas & $\begin{array}{l}\text { Wood and } \\
\text { Furniture }\end{array}$ \\
\hline \multirow[t]{6}{*}{$\begin{array}{l}2009 \\
\text { Finalized }\end{array}$} & "Software Validation" & Process & Identech & Under study. & Londrina & $\begin{array}{l}\text { Electrical and } \\
\text { Electronic } \\
\text { appliances }\end{array}$ \\
\hline & "Plastic Wood" & Product & Madeplast & $\begin{array}{l}015110000475 \\
\text { provisional number }\end{array}$ & $\begin{array}{l}\text { São José dos } \\
\text { Pinhais }\end{array}$ & $\begin{array}{l}\text { Wood and } \\
\text { Furniture }\end{array}$ \\
\hline & "Safe Furniture" & $\begin{array}{l}\text { Process and } \\
\text { product }\end{array}$ & $\begin{array}{l}\text { Movelaria } \\
\text { Paranista }\end{array}$ & $\begin{array}{l}\text { MU 900I425-I } \\
\text { MU 900I433-2 } \\
(M U) 015100002278\end{array}$ & Curitiba & $\begin{array}{l}\text { Wood and } \\
\text { Furniture }\end{array}$ \\
\hline & $\begin{array}{l}\text { "Industrialization of Wild Black- } \\
\text { berries" }\end{array}$ & Product & Samalou & Under study. & $\begin{array}{l}\text { Francisco } \\
\text { Beltrão }\end{array}$ & $\begin{array}{l}\text { Food and } \\
\text { Beverages }\end{array}$ \\
\hline & “Color Ophthalmic Lens" & Product & Tooling & Under study. & Paranavaí & $\begin{array}{l}\text { Metalwork- } \\
\text { ing }\end{array}$ \\
\hline & $\begin{array}{l}\text { "PecsArt - PcDVisual Inclusion” } \\
\text { (Comunis) }\end{array}$ & Product & Kaygangue & Not applicable. & Curitiba & $\begin{array}{l}\text { Printing and } \\
\text { Publishing }\end{array}$ \\
\hline \multirow[t]{8}{*}{$\begin{array}{l}2010 \\
\text { Ongoing }\end{array}$} & $\begin{array}{l}\text { Sedapet Serge - Quality and } \\
\text { Sustainability }\end{array}$ & Product & Casulo Feliz & Under study. & Maringá & $\begin{array}{l}\text { Textile and } \\
\text { Garments }\end{array}$ \\
\hline & $\begin{array}{l}\text { Wind-Driven Alternate Piston } \\
\text { Pump }\end{array}$ & Product & ZM Bombas & Under study. & Maringá & $\begin{array}{l}\text { Metalwork- } \\
\text { ing }\end{array}$ \\
\hline & $\begin{array}{l}\text { Crockmix - Baked and Grilled } \\
\text { Goods in a Special Package for } \\
\text { the Mixture }\end{array}$ & Product & Apetitoso & Under study. & Londrina & $\begin{array}{l}\text { Food and } \\
\text { Beverages }\end{array}$ \\
\hline & $\begin{array}{l}\text { Baby popsicle enriched with } \\
\text { flavonoids }\end{array}$ & Product & $\begin{array}{l}\text { Oficina do } \\
\text { Sorvete }\end{array}$ & Under study. & Foz do Iguaçu & $\begin{array}{l}\text { Food and } \\
\text { Beverages }\end{array}$ \\
\hline & $\begin{array}{l}\text { Development of a Pressure deep } \\
\text { fryer for domestic use }\end{array}$ & Product & $\begin{array}{l}\text { Alcast do } \\
\text { Brasil Ltda. }\end{array}$ & Under study. & Palmas & $\begin{array}{l}\text { Metalwork- } \\
\text { ing }\end{array}$ \\
\hline & $\begin{array}{l}\text { Popular Housing made of Struc- } \\
\text { tural Wooden Panels - Standard- } \\
\text { izing the Alternative }\end{array}$ & Process & TecVerde & Under study. & $\begin{array}{l}\text { São José dos } \\
\text { Pinhais }\end{array}$ & $\begin{array}{l}\text { Civil Con- } \\
\text { struction }\end{array}$ \\
\hline & $\begin{array}{l}\text { Instrumentation Plant Simula- } \\
\text { tor and 3D Industrial Process } \\
\text { Control }\end{array}$ & Process & Oniria & Under study. & Londrina & $\begin{array}{l}\text { Information } \\
\text { Technology }\end{array}$ \\
\hline & $\begin{array}{l}\text { Development of an Equipment } \\
\text { for the Removal of the Cucumber } \\
\text { Pulp for } \\
\text { The Manufacture of Stuffed } \\
\text { Cucumber and Use of the Pulp in } \\
\text { the Industrialization } \\
\text { of Jam }\end{array}$ & $\begin{array}{l}\text { Process and } \\
\text { product }\end{array}$ & RJU - Cantu & Under study. & $\begin{array}{l}\text { São Jorge do } \\
\text { Oeste }\end{array}$ & $\begin{array}{l}\text { Food and } \\
\text { Beverages }\end{array}$ \\
\hline
\end{tabular}

Table 0I: Collaborative innovation projects between industries from Paraná and SENAI PR. Source: SENAI PR's Annual Management Report (20I I).

ISSN: 07 I8-2724. (http://www.jotmi.org)

Journal of Technology Management \& Innovation (c) Universidad Alberto Hurtado, Facultad de Economía y Negocios. 
projects for cooperation by SENAI (which provides services that are subsidized by the 'call to innovation' scheme) and the results of which are measured according to the incorporation of said innovation by the industry. Therefore, the companies inject equal funds as investment in their own projects and, furthermore, universities or other institutions may integrate the project teams (mixed teams), through defined agreements, involving intellectual property issues, etc. In addition to these resources, since 2009, the Ministério da Ciência e Tecnologia/MCT (the Ministry for Science and Technology), through the Conselho Nacional de Desenvolvimento Científico e Tecnológico/CNPq (National Department of Scientific and Technological Development), has been investing resources in approved projects by subsiding Industrial Technology Scholarships (DTI), through a specific agreement between the institutions. As of 2004, all over the country and through the SENAI agencies in each state, 895 projects have already applied, of which 209 were approved, with $35.7 \%$ of incorporation of the results by the partner companies. These numbers were validated in 2010 by the Sociedade Brasileira Pró-Inovação (PROTEC) and the Universidade Federal do Rio de Janeiro (UFRJ).

In the case of SENAI PR, 85 of the projects submitted since 2004, 26 have been approved, 17 have been developed and 07 others commenced in October 2011 (through the agreement for cooperation signed between the parties). The projects that have already been developed present good indices regarding the incorporation of results by partner companies. The resources invested in the projects, between 2004 and $20 \mathrm{II}$, are represented as being $33 \%$ by SENAI,
$17 \%$ by SENAI PR, $39 \%$ by partner companies, $6 \%$ by MCT/ $\mathrm{CNPq}$ and $5 \%$ by other partners (universities, colleges, other companies and institutions).

Two approved projects were excluded from the sample because the companies did not proceed with the project and it was not possible to contact their managers. Another characteristic to be emphasized is that most of the projects are related to incremental innovations, adapted to the budget and terms determined by the regulation of the Call to Innovation, and are more likely to be inserted into the market and/or flow back to the companies.

With selection criteria, they are defined in the regulation and focus on: analysis of the projects type, company profile (proven industrial activity, commercial growth, market potential, anteriority report in patent databases and scientific periodicals, etc.), matching funds (self-investment ability of companies) and economical (generation of project team in the companies) capabilities, which signals the intention to invest in its competitiveness, as it invests in its own innovation project. After this step, those SENAI PR Units which were geographically closer to the proposing industries, which hold the human and laboratory capability for the joint development of the applied research, proceed with planning of the cooperation and the details of the proposals, with the support of SENAI PR's team of specialists in innovation projects. After completion of the portfolio that is going to be submitted to the national evaluation (activity that occurs once a year, since 2004), the final results are expected so that the development of the yearly approved projects can begin, for a period of 18 to 20 months.

\begin{tabular}{|c|c|c|c|c|c|c|c|c|c|}
\hline Industrial Sectors & $\begin{array}{l}\text { Company } \\
\text { Size.* }\end{array}$ & $\begin{array}{l}\text { Type of } \\
\text { Innovation** }\end{array}$ & $\begin{array}{l}\text { Sector's Techno- } \\
\text { logical Intensi- } \\
\text { ty*** }\end{array}$ & & & & & & \\
\hline & Small & Medium & Prod. & Proc. & Bus. & High & $\begin{array}{l}\text { Medium } \\
\text { High }\end{array}$ & $\begin{array}{l}\text { Medium } \\
\text { Low }\end{array}$ & Low \\
\hline Food and Beverages & 4 & 1 & 5 & 1 & -- & -- & -- & -- & 5 \\
\hline Textile and Garments & 2 & -- & 2 & -- & 1 & -- & -- & -- & 2 \\
\hline Wood and Furniture & 3 & -- & 2 & 2 & -- & -- & -- & -- & 3 \\
\hline Metalworking & 1 & 2 & 3 & -- & -- & -- & 3 & -- & -- \\
\hline Printing and Publishing & 1 & -- & 1 & -- & -- & -- & -- & -- & 1 \\
\hline Civil Construction & 1 & -- & -- & 1 & -- & -- & -- & -- & 1 \\
\hline $\begin{array}{l}\text { Electrical and Electronic } \\
\text { appliances }\end{array}$ & 1 & -- & -- & 1 & -- & 1 & -- & -- & -- \\
\hline Information Technology & 1 & -- & -- & 1 & -- & I & -- & -- & -- \\
\hline Total & 14 & 03 & 13 & 07 & 01 & 02 & 03 & 0 & 12 \\
\hline
\end{tabular}

Table 02: General profile of the researched industries.

* Classification of company size according to the number of people engaged (SEBRAE);

** Classification of the innovation accord to the Oslo Manual (2005);

*** Classification by Technological Intensity according to Furtado and Carvalho (2005, p. 7I-73);

ISSN: 07 I8-2724. (http://www.jotmi.org)

Journal of Technology Management \& Innovation (c) Universidad Alberto Hurtado, Facultad de Economía y Negocios. 
Table 0 I lists those projects approved and developed through cooperation between SENAI PR and companies from the Paraná industrial sector which integrate the researched sample, with required patent applications listed in the projects' scope.

Summarizing, the general profile of the industries researched (table 02) is presented below, including classification by company size and technological intensity.

According to the Oslo Manual (2005, p. II2), "Innovation in low and medium technology companies (LMT) often receives less attention than innovation in high technology companies. However, innovation in LMTs might have a substantial impact on economic growth, due to the importance of these sectors in the economy." Mostly, the companies researched fit into this category, innovating products that are easily absorbed by the market.

The nature of SENAI must be considered in the cooperation because it has an impact the planning of activities. This question directly reflects on the planning of activities, especially the procurement processes implemented by the institution, because it is controlled by specific bidding rules due to the public resources managed by SENAI. The time dedicated to the bidding process is quite different from the time required by the procurement process in private companies. This requires distinct planning of resource management by the project partners, so that the inputs, materials and other items are available for the project at the right time during development. Due to the specifics of each organization, there are different modus operandi which might act as potential barriers or facilitators, depending on the clarity of the communication process and agreement between the project partners.

\section{Strategy, structure and resources}

As a definition of strategy with innovation, one of the strategic objectives of SENAl is to foster industrial innovation and its corporate vision is to be recognized as a partner to the technology innovation industry. Therefore, SENAl's 'Call to Innovation' is just one of its activities for fulfilling that strategic objective. As a framework for innovation and located at its headquarters, SENAI PR has an Innovation Projects Management team offering support services in the entire state of Paraná. It also offers advisory support services such as Intellectual Property Rights, infrastructure, laboratorial services and provides qualified technical staff to aid research (Master's and Doctorate Degrees), allocated at Units located in several statewide municipalities.

The companies however, present different innovation strategies, according to their industrial sector, technological density, market size and extent.

Table 03 below presents the results of the studied dimension.

\begin{tabular}{|l|l|l|l|}
\hline & QUESTIONS & A & B \\
\hline I. & $\begin{array}{l}\text { Clarity about the extent that innovation is an important component of your company's } \\
\text { strategy. }\end{array}$ & 8,6 & 7,6 \\
\hline 2. & Clarity regarding the strategy for developing innovation projects through partnerships. & 8,6 & 6,9 \\
\hline 3. & $\begin{array}{l}\text { Clarity about the extent to which your company understands what strategic technolo- } \\
\text { gies are (those that are crucial for the success of the business). }\end{array}$ & 7,6 & 6,5 \\
\hline 4. & $\begin{array}{l}\text { Outsourcing practices with suitable intensity and focused on the organization's voca- } \\
\text { tional areas. }\end{array}$ & 6,5 & 5,9 \\
\hline 5. & Rules and procedures that enable creativity and innovation in the company. & 5,6 & 5,5 \\
\hline 6. & $\begin{array}{l}\text { Areas of the company with inwardly cooperation in the management process of innova- } \\
\text { tion projects. }\end{array}$ & 6,8 & 7,1 \\
\hline 7. & $\begin{array}{l}\text { Assignment of a person in charge of the development of a new product or process, } \\
\text { responsible for integrating the efforts of the company's several areas of operation. }\end{array}$ & 7,8 & 7,0 \\
\hline 8. & $\begin{array}{l}\text { Suitable resources and materials (equipment, inputs, etc.) for development of the inno- } \\
\text { vation. }\end{array}$ & 6,8 & 6,3 \\
\hline 9. & The proper lay out to stimulate innovation. & 5,9 & 5,6 \\
\hline I0. & $\begin{array}{l}\text { Proper system for the periodical evaluation of barriers and facilitators to the innovation } \\
\text { process in the company. }\end{array}$ & 5,8 & 5,4 \\
\hline
\end{tabular}

Table 03: Strategy, structure and resources. Source: developed by the authors.

ISSN: 07 I8-2724. (http://www.jotmi.org)

Journal of Technology Management \& Innovation (c) Universidad Alberto Hurtado, Facultad de Economía y Negocios. 
It is clear from these results that innovation is a component in the strategy of those organizations involved in the projects. The results of other items allow one to infer that there are several aspects to be developed in the partner organizations in order to create a complete innovation development plan, in addition to maintaining the administrative aspects focused on meeting the projects' demands. Conditions required to implement innovation in the organizational processes and leverage internal skills are the greatest challenge faced by the collaborative development of innovation projects management (JONASH, 200I).

The framework for projects is comprised of a mixed staff (institution and industry), with the definition of a person in charge (project manager assigned by SENAI). According to the aforementioned results, note that the integration of the efforts by the manager and the support staff to provide the proper resources according to the work schedule showed good results. The organization's modus operandi must be considered, as reported at the end of item 4.1 herein, and that the framework for projects is inserted as a matrix in SENAI PR's organizational structure (VASCONCELLOS; Hemsley, 2003).

One of the comments concerning this item refers to the project management system, which facilitates development of the work plan, in addition to storing records and fostering management of the knowledge generated by the innovation development research.

Since the sample consists of small and mid-size companies, the relevance of cooperation became evident as a function of the access, by the industries, to SENAI PR's framework, competences and resources (in the form of services).

\section{Human Resources and behavior}

Data surveying for this item was not comprised of research into secondary data, such as the human resources policies of the organizations involved. It was based on the perception of the respondents in view of the conditions for the collaborative development of the innovation project.

Table 04 below presents the results concerning human resources and behavior.

The low averages pertaining to certain indicators regarding a favorable climate for creativity in innovation indicate that they are not perceived by the representatives of the projects as barriers, such as:Authoritarianism, stress climate, intolerance to mistakes, criticism, envy, jealousy, etc. These results confirm that the project managers feel motivated to face the challenges and integrate the efforts of the several areas of the company in favor of the project, as per table 01 . It should also be considered that the collaborative project teams consist of employees arising from different cultures, philosophies and organizational values. In addition to these factors, each team formed after 2009 comprises a scholarship member DTI/CNPq (with no employment bond and whose only goal is developing the project), and the group requires autonomy for the development of the projects. An encouraging innovation climate requires tolerance, trust, acceptance of differences, support from team leaders, etc. and, therefore, skills additional to those involved in the projects

\begin{tabular}{|c|l|l|l|}
\hline & QUESTIONS & $\mathrm{A}$ & $\mathrm{B}$ \\
\hline II. & Human Resources Strategic Development Plan & 4,7 & 4,7 \\
\hline I2. & Motivation related to carrier remuneration policies. & 5,6 & 4,7 \\
\hline I3. & Authoritarianism as a barrier to creativity and innovation. & 3,8 & 3,5 \\
\hline I4. & Stress climate due to power dispute, as a barrier to innovation. & 3,0 & 2,8 \\
\hline I5. & The low level of error tolerance. & 3,3 & 3,4 \\
\hline I6. & Criticism and mockery climate towards new ideas. & 1,7 & 2,5 \\
\hline I7. & $\begin{array}{l}\text { Reward system (remuneration or others) for the ones in charge of successful innova- } \\
\text { tions. }\end{array}$ & 4,5 & 3,2 \\
\hline I8. & Habits and tradition as barriers to creativity and innovation. & 3,0 & 3,9 \\
\hline I9. & $\begin{array}{l}\text { Envy and jealousy triggered by new ideas which negatively impacts creativity and inno- } \\
\text { vation. }\end{array}$ & 3,1 & 2,7 \\
\hline 20. & Autonomy to experience new things. & 6,9 & 4,8 \\
\hline 21. & Use of creativity stimulation techniques. & 4,1 & 3,2 \\
\hline
\end{tabular}

Table 04: Human Resources and behavior. Source: developed by the authors.

ISSN: 07 I 8-2724. (http://www.jotmi.org)

Journal of Technology Management \& Innovation (C) Universidad Alberto Hurtado, Facultad de Economía y Negocios. 
(ALENCAR, 1997; Cardinal Et Al, 1998; Vasconcellos; Hemsley, 2003; Parolin;Albuquerque, 20I0).

Conversely, those aspects related to the development of human resources and remuneration and carrier policies for the associates involved in innovation projects showed room for an improved definition. The creativity perceived as input and output to the innovation management process needs to be fed in the organizational context, through policies and actions which ascertain that people are the differential for achieving results with innovation (ALBUQUERQUE, 2002; Leede; Looise, 2005; Aliaga, 2005; Parolin;Albuquerque, 2010).

\section{Management of technological innovation}

In order to analyze the results of this set of questions, one must consider that the respondents are interconnected with the innovation strategies in their organizations from the initial execution of the project with which they are involved. Their perceptions' bottom line is the project itself and, as they get involved in this action, they confront the existing structures for the development of technological innovation projects. As an example, for selecting proposals issued by the industries, SENAI PR carries out prior research into invention, patent databases and scientific periodicals (technological vigilance). Several associates who are willing to perform the role of project manager start to better understand this activity and its importance from this moment on. The same occurs to partner industries, because only a few of them rely on a formal support structure for their technological innovation in view of the size, segment and market they operate.
Table 05 below presents the results regarding the technology innovation management in the collaborative management of projects.

The data refer to the strategic guidelines and systemized technological innovation management processes and focus on opportunities and improvements for an increasingly fit baseline as to the collaborative innovation strategy. Themes such as patent policies, technological trends and negotiation techniques are crucial for the innovation culture and require increasing efforts for greater maturity and improved support frameworks for the industrial community.

The companies present clear judgment about the guidelines for acquisition of technology, internal development (R\&D), technology transfer agreements or development of projects in partnership with other entities. The results are ratified in item 4.5, especially in ascertaining the fact that the partnership reported in this case study occurred so that the company could become more innovative.

\section{Collaborative management of innovation projects}

To analyze the results for this item, two peculiarities are reconsidered for the case being studied. The first one is that the scientific and technological community has little comprehension of the fact that SENAI PR is regimentally dedicated to cooperating in the development of technological researches focused on the industry (applied research), as mentioned in item 4.I. Each year, when the Innovation Notice is released and announced, several companies show

\begin{tabular}{|l|l|l|l|}
\hline QUESTIONS & A & B \\
\hline 23. & $\begin{array}{l}\text { Systematic monitoring of external sources of information regarding technological } \\
\text { trends. }\end{array}$ & 5,3 & 5,6 \\
tion. & $\begin{array}{l}\text { Strategic technology plan comprising the innovation project portfolio according to the } \\
\text { company's strategy, with the needs of customers and considering the actions of the } \\
\text { competition. }\end{array}$ & 5,4 & 5,9 \\
\hline 25. & $\begin{array}{l}\text { Coherence between the goals of the company with regard to market leadership and } \\
\text { investment in technology. }\end{array}$ & 6,9 & 6,0 \\
\hline 26. & $\begin{array}{l}\text { Clear guidelines for choosing between buying ready, developing internally, recruiting } \\
\text { development services, or developing in partnership with another institution. }\end{array}$ & 7,5 & 6,3 \\
\hline 27. & Evaluation of the technological capacity of the company in view of the competition. & 6,1 & 5,6 \\
\hline 28. & Patent policy, expressing when and where patenting is worthwhile. & 6,0 & 6,8 \\
\hline
\end{tabular}

Table 05: Management of technological innovation. Source: developed by the authors.

ISSN: 07I 8-2724. (http://www.jotmi.org)

Journal of Technology Management \& Innovation (c) Universidad Alberto Hurtado, Facultad de Economía y Negocios. 
some interest in presenting their projects believing it concerns the selection of proposals for access to financial resources, such as a development agency. When the notice's objective becomes evident - development of collaboration projects, with defined counter-entries between partners the interest extends to those industries that visualize the common goals, the advantages of partnerships and identification of potential barriers that normally might occur in the cooperation (TIDD et al, 2008). Therefore, the second peculiarity refers to the results produced through the cooperation for the industries, whose innovation projects are finalized with the inception of such innovation (product or process) in their businesses and market insertion. SENAI DN broadly announces the results of the projects to the nation's industrial community, with special emphasis on the partner industry, which generate spontaneous media and disclosure.

Table 06 presents the results regarding the collaborative management of technological innovation projects.

This set of questions presented the highest averages in the study and, overall, the highest averages were achieved by the respondents representing the industries, which allow us to infer that the barriers faced during cooperation did not provide a hindrance sufficient to prevent the proposed goals. One of the comments emphasized that the development of an innovation project through a partnership with an industry "allowed unprecedented professional growth and the development of a portfolio of successful cases"
There is a similarity in the results of the present research with the ones presented by PINTEC 2008 (Industrial Research of Technological Innovation, promoted by the IBGE/ Instituto Brasileiro de Geografia e Estatística) carried out with over 100 thousand companies countrywide. In the research, the item "issues or obstacles to innovation" indicated that the industries considered the following as major barriers: the high costs of innovation (73.2\%), excessive economic risks (65.9\%) and the lack of qualified personnel (57.8\%). Those are some of the elements that the cooperation among organizations for the development of research seeks to provide with the investment of resources and competencies by the parties involved, with the benefits arising from this collaboration.

The set of answers provided in this indicator shows the management effort to overcome the cultural, legal and economic barriers concerning the recent governmental mechanisms that foments cooperation between companies and universities for the development of R\&D projects. The Innovation Law (Lei 10.973/04, adjusted by Decree 5.563, from $10 / 1 / / 2005$ ), that suggests "a new regulatory milestone aiming at fomenting the generation of patents and the transfer of technology from public universities to the private sectors" (STAL: FUJINO, 2005, p. I2). Although SENAI is not mentioned in the scope of said law, the construction of environments that produce cooperation for innovation in industry is part of the entity's strategies. Furthermore, in the case under study, the cooperation does not involve the direct relation with the university, but some projects receive cooperation from the universities of Paraná.

\begin{tabular}{|l|l|l|l|}
\hline & QUESTIONS & A & $B$ \\
\hline 29. & The partnership project provided an answer to a certain key-necessity. & 7,7 & 7,1 \\
\hline 30. & The partnership project provided an answer to a certain market necessity. & 7,9 & 7,4 \\
\hline 31. & The partnership project enabled reduction of costs for research and development. & 7,8 & 7,3 \\
\hline 32. & The partnership project enabled reduction of risks involved in research and development. & 7,3 & 6,9 \\
\hline 33. & The partnership project allowed the growth of the company's product array. & 7,9 & 7,3 \\
\hline 34. & The partnership project enabled technological changes in the company. & 7,8 & 7,3 \\
\hline 35. & The partnership project enabled time improvements for the market. & 6,6 & 6,8 \\
\hline 36. & The partnership project offered an answer to competitors. & 6,4 & 5,9 \\
\hline 37. & The project was developed through a partnership, as a managerial initiative. & 7,5 & 6,4 \\
\hline 38. & The decision to develop a partnership project was made so that the company could be- & 8,4 & 7,2 \\
& come more innovative regarding its products. & & \\
\hline
\end{tabular}

Table 06: Collaborative management of innovation projects. Source: developed by the authors.

ISSN: 07I 8-2724. (http://www.jotmi.org)

Journal of Technology Management \& Innovation (c) Universidad Alberto Hurtado, Facultad de Economía y Negocios. 


\section{Final Considerations}

The study of the case about the barriers and facilitators of technological innovation projects, developed through cooperation between SENAI PR and the industries, allows for a remark that the analysis of the results must consider the innovation levels to which the country is still attracted. According to Stal and Fujino (2005), innovation incentive mechanisms are recent in the country. With the recent creation of new mechanisms to provide incentives and finance for innovation, such as the Empresa Brasileira de Pesquisa e Inovação para a Indústria/ EMBRAPII (Brazilian Industrial Research and Innovation Company - EMBRAPII), the cases that have achieved positive results, bringing competitiveness to industries, must be emphasized and socialized for theoretical and practical reflections and enable learning about how to promote and develop research projects with effective results and consequently, contribute so that companies, universities and research institutes use these innovation incentive mechanisms as quickly as possible.

The case in question evidenced the barriers and facilitators in the collaborative management of innovation projects developed in small and mid-size industries. Table 07, below, shows the main results, according to the BFI model.

The main barriers and facilitators outlined in table 07 provide a reference for companies seeking to implement innovation into their strategy. Note that the main barriers are relevant to the culture of innovation and could be minimized through company decisions for developing projects in cooperation with other organizations to make them more ompetitive.
The cooperation allowed the functions to be supplemented for the management of innovation projects. New studies are suggested regarding this concern, considering the access mechanisms currently in force in Brazil for the incentive and promotion of innovation and open innovation trends.

The primary evidence refers to the crucial role of project managers when leading the framework requirements, which strengthens the conception of the framework for projects and the conception of the matrix in the development of technological innovation projects. This strengthens the concept that people are differentials for achieving results with innovation and that the cooperation between entities and companies depends, necessarily, on people's involvement and commitment (ALIAGA, 2005; Parolin; Albuquerque, 2010).

Another important emphasis refers to the strategic guidelines for technological innovation that, for being duly reported in the structure, allow forwarding of projects until positive results are achieved at the partner industries.

All aspects surveyed by the research might become barriers or facilitators to the collaborative management of technological innovation projects, depending on the way they are led, according to the perception of the authors involved and the environment in which they are manifested.

\begin{tabular}{|l|l|l|}
\hline BFI & Main Barriers & Main Facilitators \\
\hline Strategy, structure and resources & $\begin{array}{l}\text { Standards and procedures which } \\
\text { hinder creativity and innovation. }\end{array}$ & $\begin{array}{l}\text { High relevance placed on innova- } \\
\text { tion as an organizational strategy. }\end{array}$ \\
\hline Human resources and behavior & $\begin{array}{l}\text { Tense atmosphere and dispute for } \\
\text { power }\end{array}$ & $\begin{array}{l}\text { Importance of autonomy to try } \\
\text { new approaches. }\end{array}$ \\
\hline Technological innovation management & $\begin{array}{l}\text { Sparse monitoring of external } \\
\text { sources of information providing } \\
\text { technological tendencies. }\end{array}$ & $\begin{array}{l}\text { Clear guidelines for purchasing or } \\
\text { developing technology in partner- } \\
\text { ship with another institution. }\end{array}$ \\
\hline $\begin{array}{l}\text { Collaborative innovation projects manage- } \\
\text { ment }\end{array}$ & $\begin{array}{l}\text { Belief that the project developed } \\
\text { must be a response to the compe- } \\
\text { tition. }\end{array}$ & $\begin{array}{l}\text { Company decision to develop a } \\
\text { cooperative project aiming to make } \\
\text { it more innovative and competitive. }\end{array}$ \\
\hline
\end{tabular}

Table 07: Main BFI results

ISSN: 07 I8-2724. (http://www.jotmi.org)

Journal of Technology Management \& Innovation (c) Universidad Alberto Hurtado, Facultad de Economía y Negocios. 


\section{References}

ALBUQUERQUE, L. G. (2002). A gestão estratégica de pessoas. In FLEURY, M ${ }^{a}$. T. L (Org.). As pessoas na organização. Ed. Gente, São Paulo, 35-50.

ALENCAR, E. (I997). A gerência da criatividade. Ed. Makron Books, São Paulo.

ALIAGA, O.A. (2005).A study of innovative human resource development practices in Minnesota companies. Tese de Doutorado em Psicologia. University of Minnesota. http:// richardswanson.com/hrdrcreports/Aliaga-2005innovation. pdf. [Accessed November, 4, 20I I].

AMABILE, T. M. (1998). How to kill creativity. Harvard Business Review. Boston, sept/oct, v. 76, $5^{a}$ ed., 76-87.

CARDINAL, G.; Guyonnet, J. F.; Pouzoullic, B. (1998). La dinámica de la confianza: construir la cooperación en los proyectos complejos. Desafío Ediciones.

CASADO,T. (2002).A motivação e o trabalho. In FLEURY, Ma. T. L (Org.). As pessoas na organização. Ed, Gente, São Paulo, 247-258.

DUTRA, J. S. (2002). Gestão de pessoas: modelo, processos, tendências e perspectivas. Edit. Atlas, São Paulo.

EKVALL, G. (1996). Organizational climate for creativity and innovation. European Journal of Work and Organizational Psychology. 5(I), I05-I23.

ENKEL, E.;M <, H. (2009). Open R\&D and open innovation: exploring the phenomenon. R\&D Management. 39 (4).

FARIAS, O. O. de; Akabane, G. K.; Bonfim,W. B. (2006) A inovação tecnológica no Estado de São Paulo e a nova Lei de Inovação. Anais do XIII SIMPEP. Bauru, São Paulo.

FERRIS, G. ; Hochwart,W.A.; Buckley, M. R.; Harrel-Cook, G.; Frink, D. D. (1999). Human Resources Management: Some New Directions. Journal of Management. 25(3), 385-4I5.

FINANCIADORA DE ESTUDOS E PROJETOS (2005). Manual de Oslo. $3^{\mathrm{a}}$. ed. Ministério da Ciência e Tecnologia, Rio de Janeiro. www.finep.gov.br. [Accessed October 25, 20I I].

FURTADO, A. T.; Carvalho, R. Q. (2005). Padrões de intensidade tecnológica da indústria brasileira: um estudo comparartivo com os países centrais. Revista São Paulo em Perspectiva. 19 (I), jan./ mar, 70-84.
GIL, A. C. (1999). Métodos e técnicas de pesquisa social. $5^{a}$ ed. Edit. Atlas, São Paulo.

INSTITUTO BRASILEIRO DE GEOGRAFIA E ESTATÍSTICA (2008). Pesquisa Industrial de Inovação Tecnológica/ PINTEC. IBGE. http://www.ibge.gov.br/home/estatistica/economia/industria/pintec/2003/default.shtm. [Accessed October $25,2011]$.

JONASH, R. S. (200I) O valor da inovação: como as empresas mais avançadas atingem alto desempenho e lucratividade. Edit. Campus, Rio de Janeiro.

LAURSEN, K.; Foss, N. J. (2003). New human resource management oractices, complementarities and the impact on innovation performance. Cambridge Journal of Economics. 243-263.

LEEDE, J. De; Looise, J. K. (2005). Innovation and HRM: towards an integrated framework. Creativity and Innovation Management. I4 (2), I08-1I7.

McLEAN, L. (2005). Organizational culture's influence on creativity and innovation: a review of the literature and implications for human resource development. Advances in Developing Human Resources. 7(2), 226-246.

MARTIN-ALCAZAR, F.; Romero-Fernández, P. M.; SánchezGardey, G. et al (2005). Strategic human resource management: integrating the universalistic, contingent, configurational and contextual perspectives. International Journal of Human Resource Management. 16:5, May, 633-659.

MINTZBERG, H. A criação artesanal da estratégia. In Montgomeery, C. (1998). Estratégia: a busca da vantagem competitiva. Edit. Campus, Rio de Janeiro.

MIOTTI, L.; F. Sachwald (2003). Co-operative R\&D: why and with whom?: An integrated framework of analysis. Research Policy, 32, p. I 48I-1499.

MOTA, T. L. N. G.; Lucchesi, R. (1998). Arranjos interinstitucionais como indutores de inovação. In: Anais do Simpósio Gestão de Inovação Tecnológica. PGT-USP, São Paulo.

NOLAN, R. L.; Croson, D. C. (1996). Destruição criativa: um processo de seis etapas para transformar sua organização. Trad. Priscilla Martins Celeste, Ana Beatriz Rodrigues. Edit. Campus, Rio de Janeiro.

PAROLIN, S. R. H.;Albuquerque, L. G. (20I0). Gestão de pessoas para a criatividade em organizações inovativas. Revista Eletrônica de Administração. Edição 67, 16(3), set/ dez, 268297. 
REIS, D. R.; Carvalho, H. G. (2002). Gestão tecnológica e inovação. In BASTOS, João Augusto S.A. (Org.). Capacitação tecnológica e competitividade: o desafio para a empresa brasileira. IEL/PR, Curitiba, 53-75.

RICHARDSON, R. J. (1989). Pesquisa social: métodos e técnicas. Edit. Atlas, São Paulo.

ROESCH, S. Ma A. (1999). Projetos de estágio e de pesquisa em administração. $2^{a}$ ed. Edit. Atlas, São Paulo.

SATO, C. E. Y.; Dergint. D. E. A.; Hatakeyama; K. (2005). Gerenciando Redes Colaborativas, Complexidade e Estratégias Tecnológicas em Integração de Sistemas. Anais do XI Seminário Latino Ibero americano de Gestión Tecnológica.

SBRAGIA, R. (Coord.); Stal, E.; Campanário, M.; Andreassi, T. (2006). Inovação: como vencer esse desafio empresarial. Clio Editora, São Paulo.

SERVIÇO NACIONAL DE APRENDIZAGEM INDUSTRIAL DO PARANÁ (20II). Relatório Anual de Gestão. SENAI PR, Curitiba.

SLUIS, L. E. C.Van der (2004). Desinging the workplace for learning and innovation. Development and learning organizations. 18 (5), I0-13.

SOCIEDADE BRASILEIRA PRÓ-INOVAÇÃO (2010). Programa SENAI de Inovação: avaliação dos resultados e sugestões de aperfeiçoamento. PROTEC/ UFRJ, Rio de Janeiro.

STAL, E.; Fujino, A. (2005). As relações universidade-empresa no Brasil sob a ótica da Lei de Inovação. RAl - Revista de Administração e Inovação. São Paulo, 2 (I), 5-19.

SWAN, F.; Sue, N.; Scarbrough, H.; Hislpo, D. (1999). Knowledge management and innovation: networks and networking. Journal of Knowledge Management. 3 (4), 262-275.

TIDD, J.; Bessant, J.; Pavitt, K. (2008). Gestão da Inovação. Tradução de Elizamari Rodrigues Becker et al. $3^{\text {a }}$. Edição. Edit. Bookman, Porto Alegre.

TIGRE, P. B. (2006). Gestão da inovação: a economia da tecnologia no Brasil. Edit. Elsevier, Rio de Janeiro.

VASCONCELLOS, E.; Hemsley, J. (2003). Estrutura das organizações: estruturas tradicionais, estruturas para inovação, estrutura matricial. Edit. Pioneira Thomson Learning, São Paulo.
PAROLIN, S. R. H.; Bordignon, J. (2006). Barreiras e facilitadores à inovação: o caso Nutrimental S/A. Revista de Economia Mackenzie. 4 (4), I2-34.

YIN, R. K. (200I). Estudo de caso: planejamento e método. Trad. Daniel Grassi. 2a. ed. Edit. Bookman, Porto Alegre.

ZELL, D. (200I). Overcoming Barriers to Work Innovations: Lessons Learned at Hewlet-Packard. Organizational Dynamics. Summer, Vol. 30 Issue I, p77-86, I0p. 